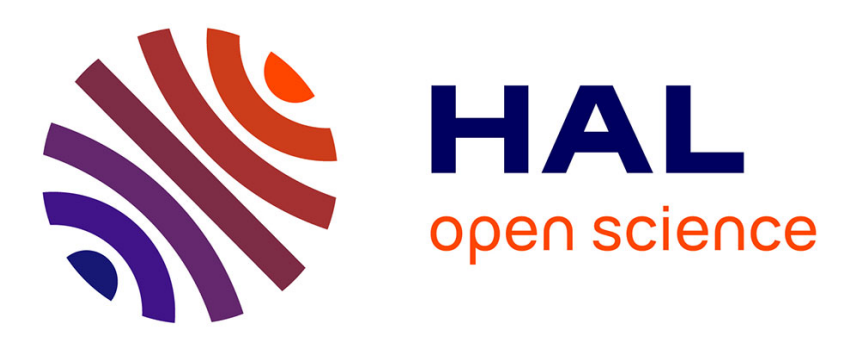

\title{
Effect of the variations of clinker composition on the poroelastic properties of hardened class G cement paste
}

\author{
Siavash Ghabezloo
}

\section{To cite this version:}

Siavash Ghabezloo. Effect of the variations of clinker composition on the poroelastic properties of hardened class G cement paste. Cement and Concrete Research, 2011, 41 (8), pp.920-922. 10.1016/j.cemconres.2011.03.022 . hal-00627515

\section{HAL Id: hal-00627515 https://hal.science/hal-00627515}

Submitted on 28 Sep 2011

HAL is a multi-disciplinary open access archive for the deposit and dissemination of scientific research documents, whether they are published or not. The documents may come from teaching and research institutions in France or abroad, or from public or private research centers.
L'archive ouverte pluridisciplinaire HAL, est destinée au dépôt et à la diffusion de documents scientifiques de niveau recherche, publiés ou non, émanant des établissements d'enseignement et de recherche français ou étrangers, des laboratoires publics ou privés. 


\title{
Effect of the variations of clinker composition on the poroelastic properties of hardened class $\mathrm{G}$ cement paste
}

\author{
Siavash Ghabezloo \\ Université Paris-Est, Laboratoire Navier-CERMES, Ecole des Ponts ParisTech, France
}

\begin{abstract}
The effect of the variations of clinker composition on the poroelastic properties of class $\mathrm{G}$ oil-well cement pastes is studied using a multiscale homogenization model. The model has been calibrated in a previous work based on the results of a laboratory study. Various compositions of class $\mathrm{G}$ cements from literature are used in a hydration model to evaluate the volume fractions of the microstructure constituents of hardened cement paste. The poroelastic parameters such as drained bulk modulus, Biot coefficient, Skempton coefficient are evaluated using the homogenization model. The results show that the variations in chemical composition of class $G$ cements have not an important effect on the variations of the poroelastic properties.
\end{abstract}

Please cite this paper as: Ghabezloo S. (2011) Effect of the variations of clinker composition on the poroelastic properties of hardened class G cement paste, Cement and Concrete Research, DOI:10.1016/j.cemconres.2011.03.022

Keywords: Cement Paste (D), Clinker (D), Mechanical Properties (C), Elastic Moduli (C), Micromechanics (C)

\section{Introduction}

Oil-well cements have a wide application in exploration and production of oil and gas, and also for sealing water wells, waste disposal wells and geothermal wells. The American Petroleum Institute (API) Standard specifies eight classes of oil-well cements for use at different well depths and conditions. Oil-well cements are specified in classes $\mathrm{A}$ to $\mathrm{H}$ and different grades corresponding to ordinary $(\mathrm{O})$, medium sulphate-resistant (MSR) and high sulphate-resistant (HSR) [1]. These classes of oil-well cement have different requirements in terms of chemical composition and physical properties. For example, the HSR class $\mathrm{G}$ cement requires, among other specifications, a $\mathrm{C}_{3} \mathrm{~S}$ volume fraction between 0.48 and $0.65, \mathrm{C}_{3} \mathrm{~A}$ volume fraction smaller than 0.03 and $\mathrm{C}_{4} \mathrm{AF}$ volume fraction smaller than 0.24. Among these oilwell cements, the classes $\mathrm{G}$ and $\mathrm{H}$ are the most widely used ones.

Email address: siavash.ghabezloo@enpc.fr (Siavash Ghabezloo)

${ }^{1}$ Siavash Ghabezloo, Laboratoire Navier-CERMES, Ecole des Ponts ParisTech, 6-8 Av. Blaise Pascal, Cité Descartes, Champs sur Marne, 77455 Marne la Vallée Cedex 2, France

Preprint submitted to Cement and Concrete Research
The knowledge of the poromechanical behaviour of the oil-well cement is essential for the prediction of the well performance during the life of the well. Recently, Ghabezloo et al. [2, 3, 4, 5] studied experimentally the thermo-poro-mechanical behaviour of a hardened oilwell cement paste. The evaluated poroelastic parameters are presented in Table (1) in which $K_{d}$ and $K_{u}$ are respectively drained and undrained bulk modulus, $G$ is shear modulus, $b$ and $B$ are respectively Biot and Skempton coefficients. The definitions of these parameters are presented in [3]. These parameters are evaluated for a cement paste prepared with a class $\mathrm{G}$ cement at $\mathrm{w} / \mathrm{c}=0.44$ and hydrated at $90^{\circ} \mathrm{C}$ for at least 90 days in saturated condition. It is known that the physical and mechanical properties of cement paste vary with clinker composition, water-to-cement ratio, cement age and curing conditions. Because of its very low permeability, the complete characterization of the poromechanical properties of the hardened cement past in an experimental study would be very expensive and time consuming. It is thus interesting to find alternative ways to evaluate the poroelastic properties of cement pastes corresponding to different conditions. This is done by Ghabezloo $[6,7]$ by association of the experimental re- 
sults of Ghabezloo et al. [2, 3, 4] with micromechanics modelling and homogenization method. A multi-scale homogenization model is calibrated on the experimental results and is used to extrapolate the thermo-poroelastic parameters to cement pastes with different waterto-cement ratios. These parameters, which are evaluated experimentally for $\mathrm{w} / \mathrm{c}=0.44$, are predicted using the homogenization model for $\mathrm{w} / \mathrm{c}$ between 0.4 and 0.65 . The predictive capacity of the model is verified in [6] by comparing the evaluated Young's modulus with some experimental results from literature. The model permits also the evaluations of pore volume bulk modulus and thermal expansion which are difficult to evaluate experimentally. This homogenization model is used here to study the effect of the variations in the composition of class $\mathrm{G}$ cement on its poroelastic properties.

Table 1: Experimentally evaluated poroelastic parameters of hardened class $\mathrm{G}$ cement paste $[2,3]\left(\mathrm{w} / \mathrm{c}=0.44\right.$, hydrated at $90^{\circ} \mathrm{C}$ and tested at laboratory temperature)

\begin{tabular}{ccccc}
\hline $\begin{array}{c}K_{d} \\
(\mathrm{GPa})\end{array}$ & $\begin{array}{c}\mathrm{b} \\
(-)\end{array}$ & $\begin{array}{c}\mathrm{G} \\
(\mathrm{GPa})\end{array}$ & $\begin{array}{c}\mathrm{B} \\
(-)\end{array}$ & $\begin{array}{c}K_{u} \\
(\mathrm{GPa})\end{array}$ \\
\hline 8.7 & 0.59 & 5.7 & 0.4 & 11.2 \\
\hline
\end{tabular}

For each class of oil-well cement, API specifies requirements in terms of maximum volume fractions of different constituents of clinker, but within these limitations the exact composition of the clinker may be different from one cement to another. Table (2) presents the compositions of five different class $\mathrm{G}$ cements from literature. The experimental study of Ghabezloo et al. [3] is performed using the cement G1.

Table 2: Compositions of different class G oil-well cements

\begin{tabular}{cccccc}
\hline Cement & $\mathrm{C}_{3} \mathrm{~S}$ & $\mathrm{C}_{2} \mathrm{~S}$ & $\mathrm{C}_{3} \mathrm{~A}$ & $\mathrm{C}_{4} \mathrm{AF}$ & Reference \\
\hline $\mathrm{G} 1$ & 0.629 & 0.140 & 0.018 & 0.126 & {$[3]$} \\
$\mathrm{G} 2$ & 0.512 & 0.270 & 0.023 & 0.144 & {$[8]$} \\
$\mathrm{G} 3$ & 0.612 & 0.152 & 0.005 & 0.160 & {$[9]$} \\
$\mathrm{G} 4$ & 0.589 & 0.152 & 0.023 & 0.192 & {$[10]$} \\
$\mathrm{G} 5$ & 0.604 & 0.172 & 0.037 & 0.156 & {$[11]$} \\
\hline
\end{tabular}

Notations: C: $\mathrm{CaO}, \mathrm{S}: \mathrm{SiO}_{2}, \mathrm{~A}: \mathrm{Al}_{2} \mathrm{O}_{3}, \mathrm{~F}: \mathrm{Fe}_{2} \mathrm{O}_{3}$

Regarding these variations in the clinker composition an interesting question is raised: Is it possible to use the poroelastic parameters evaluated for cement G1 to other class $\mathrm{G}$ cements? In other words, what is the effect of the variations of the chemical composition of class $G$ cements on their poroelastic properties? This question is studied in this paper using the homogenization model calibrated by Ghabezloo [6] for the poroelastic properties of the hardened cement paste.

\section{Clinker composition and cement paste mi- crostructure}

The cement clinker is composed of four main phases: $\mathrm{C}_{3} \mathrm{~S}, \mathrm{C}_{2} \mathrm{~S}, \mathrm{C}_{3} \mathrm{~A}$ and $\mathrm{C}_{4} \mathrm{AF}$ where in the standard cement chemistry the notation $\mathrm{C}$ stands for $\mathrm{CaO}, \mathrm{S}$ for $\mathrm{SiO}_{2}$, $\mathrm{A}$ for $\mathrm{Al}_{2} \mathrm{O}_{3}$ and $\mathrm{F}$ for $\mathrm{Fe}_{2} \mathrm{O}_{3}$. The setting and hardening of the cement paste are the results of complex reactions, called hydration reactions, between clinker phases and water. In a simplified view, the main phases of the microstructure of the cement paste are calciumsilicate-hydrate $(\mathrm{C}-\mathrm{S}-\mathrm{H})$, Portlandite $(\mathrm{CH})$, Aluminates (AL), unhydrated clinkers (CK) and macro-porosity (V). More details about the microstructure of cement paste are presented in [6]. The homogenization method needs the evaluation of the volume fractions of different constituents of the microstructure of cement paste. These volume fractions can be evaluated by knowing cement composition, water-to-cement ratio and degree of hydration, using the method presented by Bernard et al. [12] which is explained in details in [6]. This method assumes simple stoichiometric reactions for the hydration of the four dominant compounds in Portland cement. The complete set of chemical reactions is presented in [13]. The following relations show the production of C-S-H and $\mathrm{CH}$ during the hydration of $\mathrm{C}_{3} \mathrm{~S}$ and $\mathrm{C}_{2} \mathrm{~S}$ :

$$
\begin{aligned}
& \mathrm{C}_{3} \mathrm{~S}+5.3 \mathrm{H} \rightarrow \mathrm{C}_{1.7}-\mathrm{S}-\mathrm{H}_{4}+1.3 \mathrm{CH} \\
& \mathrm{C}_{2} \mathrm{~S}+4.3 \mathrm{H} \rightarrow \mathrm{C}_{1.7}-\mathrm{S}-\mathrm{H}_{4}+0.3 \mathrm{CH}
\end{aligned}
$$

For the cements presented in Table (2) the volume fractions of the microstructure phases are calculated considering $\mathrm{w} / \mathrm{c}=0.44$ and complete hydration. The results, presented in Table (3), show the effect of variations of clinker composition on the volume fractions of microstructure phases. The variations of volume fractions of C-S-H, CH and AL are smaller than $6 \%$ and the macro-porosity variations are only about $1 \%$.

\section{Effect of clinker composition on the poroelastic properties}

The homogenization model permits the evaluation of the poroelastic properties of cement paste by knowing the volume fractions and the elastic parameters of different microstructure phases. This model is calibrated based on the experimental results presented in $[2,3]$ and 
Table 3: Volume fractions of the microstructure phases of fully hydrated cement paste $(\mathrm{w} / \mathrm{c}=0.44)$

\begin{tabular}{cccccc}
\hline Cement & C-S-H & CH & AL & CK & V \\
\hline G1 & 0.575 & 0.183 & 0.130 & 0.00 & 0.112 \\
G2 & 0.591 & 0.155 & 0.148 & 0.00 & 0.106 \\
G3 & 0.565 & 0.176 & 0.142 & 0.00 & 0.117 \\
G4 & 0.533 & 0.165 & 0.190 & 0.00 & 0.112 \\
G5 & 0.554 & 0.168 & 0.172 & 0.00 & 0.106 \\
\hline
\end{tabular}

is explained in details in $[6,7]$. The needed volume fractions are presented in Table (3) and the elastic parameters of the microstructure constituents are given in [6]. The poroelastic parameters of the oil-well cements of Table (2) are evaluated using the homogenization model and presented in Table (4).

Table 4: Poroelastic parameters of different class $\mathrm{G}$ cements

\begin{tabular}{|c|c|c|c|c|c|}
\hline Cement & $\begin{array}{c}K_{d} \\
(\mathrm{GPa})\end{array}$ & $\begin{array}{c}\mathrm{b} \\
(-)\end{array}$ & $\begin{array}{c}\mathrm{G} \\
(\mathrm{GPa})\end{array}$ & $\begin{array}{l}\text { B } \\
(-)\end{array}$ & $\begin{array}{c}K_{u} \\
(\mathrm{GPa})\end{array}$ \\
\hline G1 & 8.54 & 0.598 & 5.76 & 0.392 & 11.15 \\
\hline $\mathrm{G} 2$ & 8.40 & 0.598 & 5.71 & 0.396 & 11.00 \\
\hline G3 & 8.35 & 0.606 & 5.65 & 0.396 & 10.99 \\
\hline G4 & 8.35 & 0.603 & 5.66 & 0.396 & 10.97 \\
\hline G5 & 8.53 & 0.595 & 5.77 & 0.396 & 11.16 \\
\hline
\end{tabular}

The predicted parameters for different cements vary in a very narrow range. The drained bulk modulus varies between 8.35 and $8.54 \mathrm{GPa}$ that is less than $5 \%$ variation. Similarly, Biot and Skempton coefficients, the shear modulus and the undrained bulk modulus show small variations due to the difference between the chemical compositions of class $\mathrm{G}$ cements. These small variations are mainly due to the small variations of volume fractions of microstructure constituents in Table (3). The results show that the variations of the clinker composition, in the limits of the values in Table (2), have not an important effect on the poroelastic properties of hardened class $\mathrm{G}$ cement paste.

\section{Conclusions}

The effect of the variations of clinker composition on the poroelastic properties of class $G$ oil-well cement pastes is studied using a multiscale homogenization model. Various chemical compositions of class $G$ cements from literature are used to evaluate the poroelastic parameters of the hardened cement paste such as drained bulk modulus, Biot coefficient, Skempton coefficient, etc. The results show that the difference in the chemical compositions of these cements has not an important effect on the variations of the poroelastic properties. The variation of the drained bulk modulus of different cements at the same water-to-cement ratio is evaluated less than $5 \%$. Consequently the poroelastic parameters evaluated by Ghabezloo et al. [2, 3] can be used for other class $\mathrm{G}$ cement pastes corresponding to different clinker compositions. The use of homogenization method permits to extrapolate the results of an experimental study on a particular cement paste to other cement pastes with different chemical composition. This is a considerable advantage that gives the possibility of parametric study and reduces the number of needed tests to evaluate the poroelastic properties of cement pastes corresponding to different conditions.

\section{References}

[1] E. Nelson, Well cementing, Elsevier Science Ltd, 1990.

[2] S. Ghabezloo, Comportement thermo-poro-mécanique d'un ciment pétrolier, Ph.D. thesis, Ecole des Ponts ParisTech (2008).

[3] S. Ghabezloo, J. Sulem, S. Guédon, F. Martineau, J. SaintMarc, Poromechanical behaviour of hardened cement paste under isotropic loading, Cement and Concrete Research 38 (12) (2008) 1424 - 1437.

[4] S. Ghabezloo, J. Sulem, J. Saint-Marc, The effect of undrained heating on a fluid-saturated hardened cement paste, Cement and Concrete Research 39 (1) (2009) 54 - 64.

[5] S. Ghabezloo, J. Sulem, J. Saint-Marc, Evaluation of a permeability-porosity relationship in a low-permeability creeping material using a single transient test, International Journal of Rock Mechanics and Mining Sciences 46 (4) (2009) 761 - 768.

[6] S. Ghabezloo, Association of macroscopic laboratory testing and micromechanics modelling for the evaluation of the poroelastic parameters of a hardened cement paste, Cement and Concrete Research 40 (8) (2010) 1197 - 1210.

[7] S. Ghabezloo, Micromechanics analysis of thermal expansion and thermal pressurization of a hardened cement paste, Cement and Concrete Research 41 (5) (2011) 520 - 532.

[8] G. L. Saout, E. Lcolier, A. Rivereau, H. Zanni, Chemical structure of cement aged at normal and elevated temperatures and pressures: Part i. class g oilwell cement, Cement and Concrete Research 36 (1) (2006) 71 - 78.

[9] J. Bensted, G. J. Audley, P. N. Aukett, Studies of early hydration with class $g$ oilwell cement using heatflow conduction calorimetry, Cement and Concrete Research 25 (2) (1995) 426 - 432.

[10] A. Saasen, P. A. Log, The effect of ilmenite plant dusts on rheological properties of class g oil well cement slurries, Cement and Concrete Research 26 (5) (1996) 707 - 715.

[11] P. Yan, Y. Zhou, Z. Yang, J. Qin, Microstructure formation and degradation mechanism of cementitious plugging agent slurries, Journal of Wuhan University of Technology-Materials Science Edition 22 (2007) 61-65.

[12] O. Bernard, F.-J. Ulm, E. Lemarchand, A multiscale micromechanics-hydration model for the early-age elastic properties of cement-based materials, Cement and Concrete Research 33 (9) (2003) 1293 - 1309.

[13] P. D. Tennis, H. M. Jennings, A model for two types of calcium silicate hydrate in the microstructure of portland cement pastes, Cement and Concrete Research 30 (6) (2000) 855 - 863. 